\title{
Historical perspectives of The American Association for Thoracic Surgery: Pedro J. del Nido
}

\author{
John R. Spratt, MD, MA, ${ }^{a}$ Kristine J. Guleserian, MD, ${ }^{b}$ and Sara J. Shumway, MD ${ }^{a}$
}

\footnotetext{
From the a Division of Cardiothoracic Surgery, Department of Surgery, University of Minnesota Medical School, Minneapolis, Minn; and ${ }^{\mathrm{b}}$ Division of Pediatric Cardiothoracic Surgery, University of Texas Southwestern Medical Center and Children's Medical Center, Dallas, Tex.

Disclosures: Authors have nothing to disclose with regard to commercial support.

Received for publication Oct 11, 2016; accepted for publication Oct 15, 2016; available ahead of print Nov 12, 2016.

Address for reprints: Sara J. Shumway, MD, Division of Cardiothoracic Surgery, Department of Surgery, University of Minnesota Medical School, 420 Delaware St, SE, Mayo Mail Code 195, Minneapolis, MN 55455 (E-mail: shumw001@umn.edu).

J Thorac Cardiovasc Surg 2017;153:225-7

$0022-5223 / \$ 36.00$

Copyright (C) 2016 by The American Association for Thoracic Surgery

http://dx.doi.org/10.1016/j.jtcvs.2016.10.011
}

"What is different about Pedro is his personal modesty despite his accomplishments and leadership position."

$$
\begin{aligned}
& \text { - Timothy J. Gardner, MD } \\
& \text { 82nd president of the AATS }
\end{aligned}
$$

Pedro Jose del Nido, the 95th president of The American Association for Thoracic Surgery (AATS), was born in Santiago, Chile, the younger of 2 children born to Jose del Nido, a general surgeon, and Theresa Oliveres, a veterinarian. Raised primarily by his mother and grandparents following his father's untimely death from coronary artery disease, Dr del Nido lived in Chile until moving to the United States at age 10 years when his mother took a faculty position at Michigan State University. The family moved to Wisconsin shortly thereafter, where Dr del Nido started his undergraduate work at the University of WisconsinMadison in biochemistry at age 15 . He graduated with honors (1969-1973) then went on to medical school, also at UW-Madison (1973-1977). He became interested in cardiac surgery and subsequently moved to Boston for his general surgery residency (Boston University, 1977-1982). On a blind date during his intern year he met Martha Friedman, an undergraduate at Brandeis University. They married at the end of his general surgery training.

Dr del Nido then joined the Banting Institute at the University of Toronto as a senior research fellow in cardiovascular surgery (1982-1983), where he studied myocardial protection. This would remain among his primary research interests. He stayed in Toronto for his clinical fellowships in cardiothoracic surgery (University of Toronto, 1983-1985) and pediatric cardiovascular surgery (Hospital for Sick Children, 1985-1986). One of his principal mentors during this period was Tirone David, MD, the 85th president of the AATS. After completing clinical training, Dr del Nido held clinical appointments at the University of Illinois at Chicago (1986-1989) and at the University of

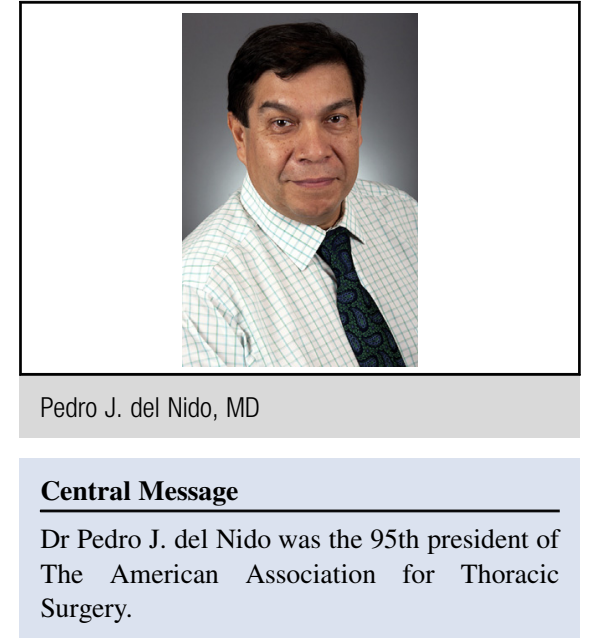

Pittsburgh (1989-1994). During this time he continued his work on myocardial energetics and cardioplegia, which lead to his first National Institutes of Health (NIH) grant in 1992. He also was instrumental in establishing pediatric extracorporeal membrane oxygenation and neonatal heart transplant programs in Pittsburgh. Dr del Nido was recruited to Boston Children's Hospital in 1994 and was promoted to chief of cardiac surgery in 2002 (Figure 1). He was appointed William E. Ladd Professor of Child Surgery in 2004; this position had been held previously by Robert Gross, MD, 44th president of the AATS, Aldo Castaneda, MD, 74th president of the AATS, and Richard Jonas, 86th president of the AATS.

Dr del Nido's laboratory has received uninterrupted NIH funding for more than 2 decades, including 11 R01 awards. His major areas of investigation have included myocardial energetics and protection, extracorporeal life support in children, and biventricular repair of many types of congenital defects. ${ }^{1,2}$ His more recent efforts have focused on the relationship between disordered heart valve development and hypoplastic left heart syndrome, device development for beating-heart intracardiac surgery using 3-dimensional echocardiography, and quantitative analysis of repair and reconstructive techniques in congenital valve disease. ${ }^{3-6}$

The most widely known result of his work in myocardial protection, and arguably his greatest single contribution to the field of cardiothoracic surgery, is del Nido cardioplegia solution. del Nido solution (DNS) is a glucose-poor hyperpolarizing crystalloid solution administered in combination (1:4) with autologous blood. Initially designed to mitigate the injurious effects of intracellular hypercalcemia 


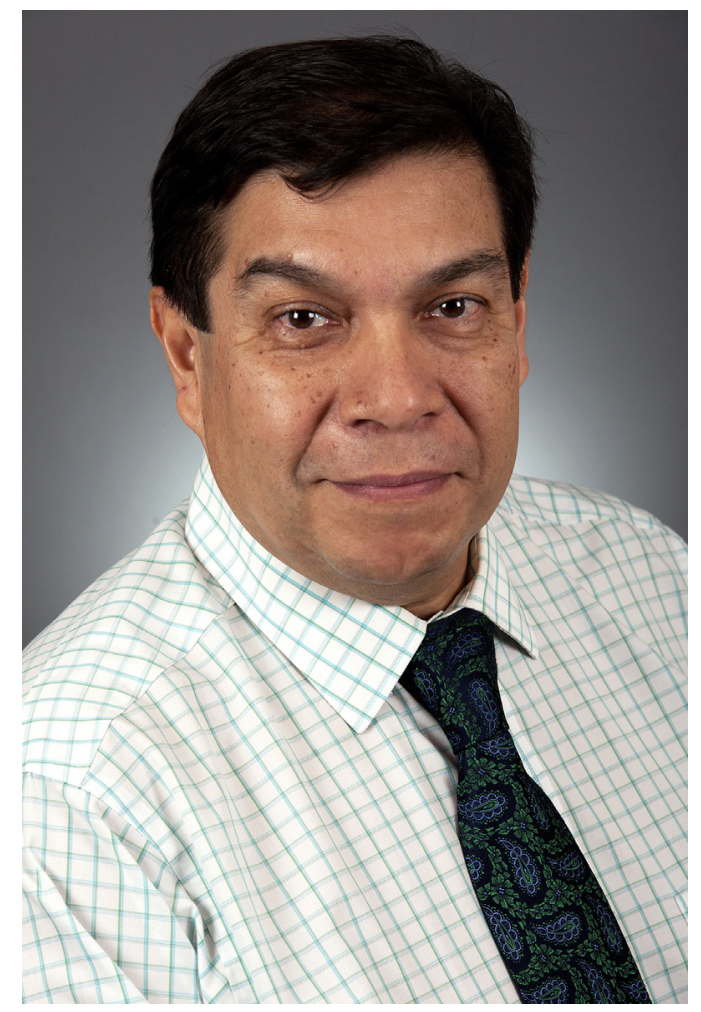

FIGURE 1. Pedro Jose del Nido, the 95th president of The American Association for Thoracic Surgery.

accompanying reperfusion of immature myocardium in infant and pediatric patients, the use of DNS has become common in the adult cardiac surgery population and indications for its use continue to expand. ${ }^{7-9}$ Most standard cardioplegia solutions are delivered antegrade and retrograde (through a coronary sinus catheter) and require repeat administration every 15 to 20 minutes while the aortic crossclamp is applied. In contrast, DNS provides adequate myocardial protection for up to 3 hours without the need for coronary sinus cannulation, making it ideal for use in open or minimally invasive valve surgery in patients without coronary artery disease. ${ }^{7,10}$

Dr del Nido is considered by his peers to be the consummate surgeon-scientist and a true triple threat, excelling in research, education, and patient care. He has published approximately 375 articles, more than 40 review articles, and many book chapters and editorials. In addition to his published work, he holds 6 patents. He has mentored nearly 40 research fellows, the majority of whom are currently in clinical surgical practice, and continues to share his passion for innovation and nontraditional approaches to complex clinical problems with colleagues. This includes seeking biventricular solutions in patients with hypoplastic left heart syndrome and other single-ventricle disorders whenever possible. Furthermore, at least 1 of his prior fellows has, in a pinch, emulated his habit of eschewing standard

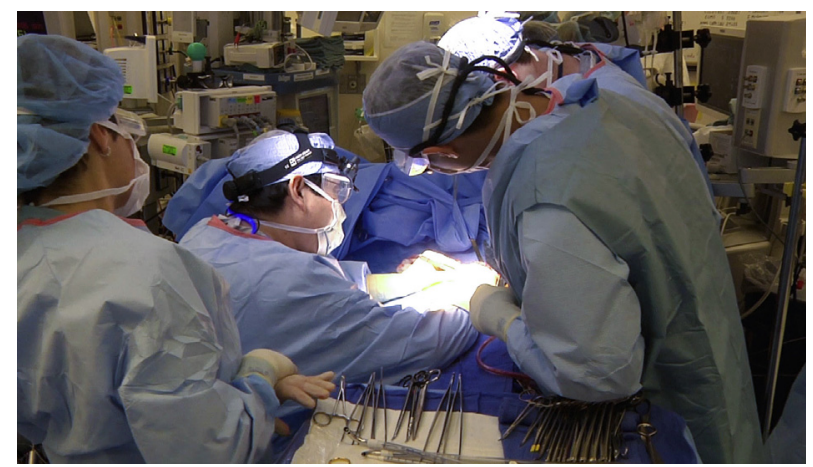

FIGURE 2. Pedro J. del Nido and his team at Boston Children's Hospital.

surgical loupes in favor of drug store reading glasses (Figure 2). In the tradition of international education and collaboration in congenital cardiac surgery, del Nido travels extensively and is considered to be a great ambassador for the AATS both at home and abroad. ${ }^{11}$

Service to national scientific organizations within and outside of the field of cardiothoracic surgery has been a staple of Dr del Nido's career. He has had a long and productive relationship with the NIH and has served on several committees and study sections. These include the Surgery and Bioengineering Study Section (2002-2004) and the Surgical Sciences, Biomedical Imaging, and Bioengineering Pediatric and Fetal Applications Study Section (20112014), serving as chair of both during his tenures. Within the field of cardiothoracic surgery, he has served as the chair of the Society of Thoracic Surgeons Workforce on Congenital Heart Surgery, as a board member of the Society of Thoracic Surgeons, and on several American Heart Association committees pertaining to cardiothoracic surgery.

In 2014 Dr del Nido was inducted as the 95th president of the AATS. He previously served the AATS as president of the Cardiac Surgery Biology Club (2004-2006), chair of the Scientific and Government Affairs Committee (20032009), and The Journal of Thoracic and Cardiovascular Surgery associate editor (2007-2014). In his presidential address, "Technological Innovation in Cardiothoracic Surgery: A Pragmatist's Approach," he urged the continual re-evaluation and testing of commonly held beliefs in the clinic and the laboratory and stressed the importance of discarding theories and practices not supported by data. He went on to urge cardiothoracic surgeons to maintain the same level of innovation and dedication to technological development that lead to rapid advancements in the field in its early days. He encouraged greater engagement with industry and regulatory bodies, allowing cardiothoracic surgeons to have greater influence on, and participation in, the development of new therapies for cardiothoracic disease. ${ }^{12}$

Dr del Nido and his wife have 4 children: Alexander, a graduate of the Harvard School of Law who currently practices in New York City; Sara, both a recent graduate of and current fellow at the Harvard School of Law; Daniel, a 


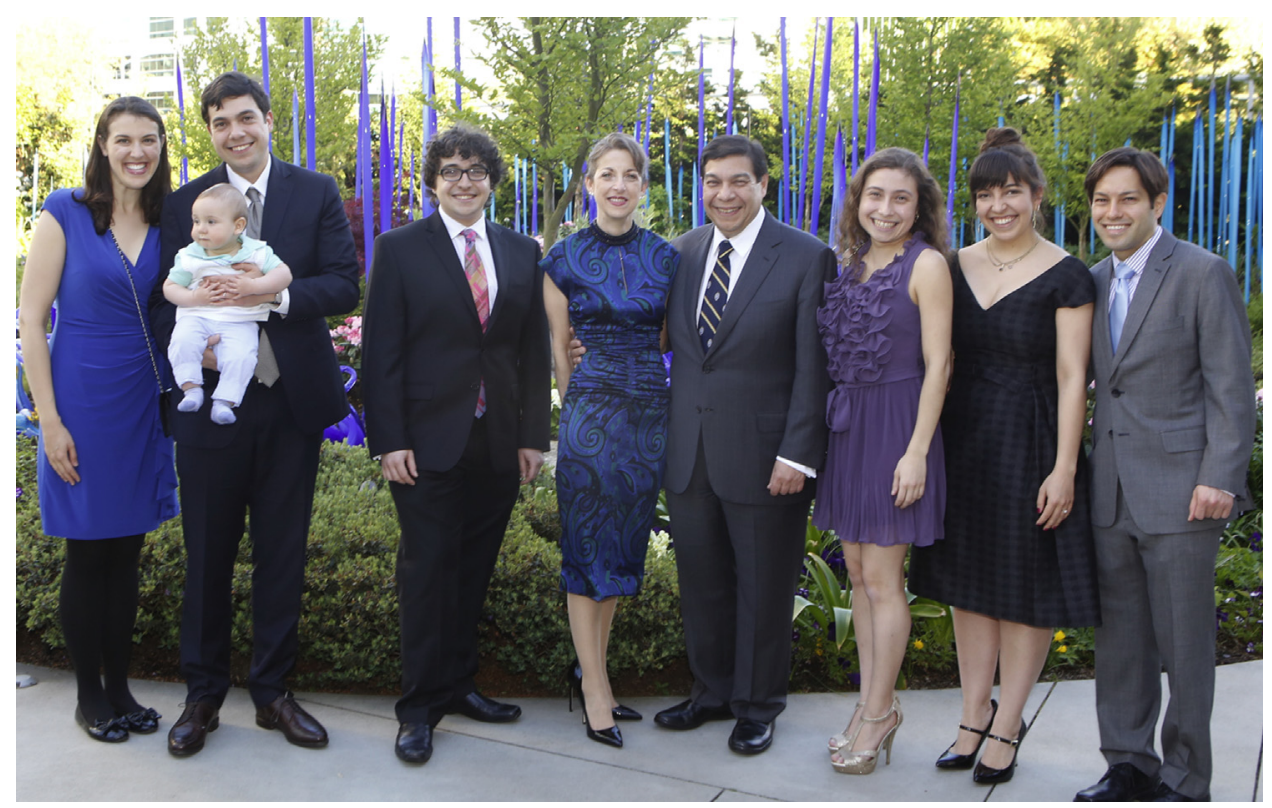

FIGURE 3. Pedro J. del Nido and his family following his presidential address at the 2015 Annual Meeting of The American Association for Thoracic Surgery, April 27, 2015, Seattle, Wash.

doctoral degree student in the Department of Religion at Columbia University; and Elizabeth, a recent graduate of State University of New York-Stony Brook who currently works for a health education firm in Boston (Figure 3). He welcomed his first grandchild, Matthew, in 2014.

The authors thank William Gaynor, MD, and Timothy Gardner, $\mathrm{MD}$, for providing assistance with the manuscript.

\section{References}

1. del Nido PJ, Armitage JM, Fricker FJ, Shaver M, Cipriani L, Dayal G, et al. Extracorporeal membrane oxygenation support as a bridge to pediatric heart transplantation. Circulation. 1994;90(5 Pt 2):II66-9.

2. Perron J, Moran AM, Gauvreau K, del Nido PJ, Mayer JE, Jonas RA. Valved homograft conduit repair of the right heart in early infancy. Ann Thorac Surg. 1999; 68:542-8.

3. Emani SM, del Nido PJ. Strategies to maintain biventricular circulation in patients with high-risk anatomy. Semin Thorac Cardiovasc Surg Pediatr Card Surg Annu. 2013;16:37-42.

4. Emani SM, Bacha EA, McElhinney DB, Marx GR, Tworetzky W, Pigula FA, et al. Primary left ventricular rehabilitation is effective in maintaining two-ventricle physiology in the borderline left heart. J Thorac Cardiovasc Surg. 2009; 138:1276-82.

5. Vasilyev NV, Kawata M, DiBiasio CM, Durand KV, Hopkins J, Traina ZJ, et al. A novel cardioport for beating-heart, image-guided intracardiac surgery J Thorac Cardiovasc Surg. 2011;142:1545-51.

6. Tang D, Yang C, Geva T, Rathod R, Yamauchi H, Gooty V, et al. A multiphysics modeling approach to develop right ventricle pulmonary valve replacement surgical procedures with a contracting band to improve ventricle ejection fraction. Comput Struct. 2013;122:78-87.

7. Mick SL, Robich MP, Houghtaling PL, Gillinov AM, Soltesz EG, Johnston DR, et al. del Nido versus Buckberg cardioplegia in adult isolated valve surgery. J Thorac Cardiovasc Surg. 2015;149:626-34; discussion 634-6.

8. Sorabella RA, Akashi H, Yerebakan H, Najjar M, Mannan A, Williams MR, et al. Myocardial protection using del Nido cardioplegia solution in adult reoperative aortic valve surgery. J Card Surg. 2014;29:445-9.

9. Matte GS, del Nido PJ. History and use of del Nido cardioplegia solution at Boston Children's Hospital. J Extra Corpor Technol. 2012;44:98-103.

10. Kim K, Ball C, Grady P, Mick S. Use of del Nido cardioplegia for adult cardiac surgery at the Cleveland Clinic: perfusion implications. J Extra Corpor Technol. 2014; 46:317-23.

11. Fraser CD. Preserving our international heritage of education in congenital heart surgery. J Thorac Cardiovasc Surg. 2014;148:377-8.

12. del Nido PJ. Technological innovation in cardiothoracic surgery: a pragmatist's approach. J Thorac Cardiovasc Surg. 2015;150:755-61. 